\title{
Teachers and Students: How to Enter the Education World
}

\author{
Lianjin Tian \\ Yibin University, Sichuan Province, P. R. China
}

\begin{abstract}
Education is essentially the soul and spirit of the human being, the growing maturity of the soul and spirit is the key to education, and education not just means the accumulation of knowledge and understanding. I will analyze the three ideas or hypotheses of education: Education should be leading to the human being world; education should be accessible to both the knowledge and life world; education should open into the soul and spirit world. The aim of this paper is to wake up the teachers to shape the spirit and soul of the students as the ultimate value so that each student not only become a person of knowledge and capability, but as a soul and spirit person.
\end{abstract}

KEYWORD: Teachers and students; the education world; the human being; knowledge and life; soul and spirit

\section{INTRODUCTION}

As we all know, the teachers should have professional knowledge, professional skills and professional attitude so as to educate the students well. How to educate the students well, Shulman, the Carnegie Foundation for the Advancement of Teaching thought that "to be responsible for and have the duty to serving for the other people of the society; to grasp and understand some academic and theory; to have the proficient ability to take part in experiment and practice in some fields; to have the ability to judge inevitably under conditions of uncertainty; to have the ability to study continually from a experience as the interactive needs of theory and practice and with professional groups of teachers to monitor the quality and continuous learning." Japanese scholar Sato Manabu (2003) characterized this analysis as follows: "Skilled personnel model of professional practical is to abstract the complex situations and events, which can be summed up as simply as possible express the concept and principles, thus broadening the definitiveness, but 'Reflective practitioner' model of professional practical, it is to explain seemingly the diversity and complexity of simple situations and events and actually inquire uncertainty of the world indepthly."[1]In this inquiry and expression, the former uses of paradigm style, but the latter uses narrative style. The existing administration system of education is a bureaucratic organization where the teachers are in the bottom of the management. Such a system emphasizes organizational effectiveness, efficiency, a commercial objective shows the status and value of the human being are stripped away, which has formed a worldwide commercial or market-oriented model. As for many researchers, education should pay attention to the complexity and uncertainty of the practical process, but how to implement the practice process of education and how to deal with the complexity and indeterminacy, theoretical considerations are not enough. deal with the complexity and indeterminacy, theoretical considerations are not enough.

\section{IDEAS OR HYPOTHESES}

Education based on ideas or hypothesis can be full of vitality. Plato advocated that "education is the turn or awakening of the soul", and Confucius believed that "education is how to inspire the students." Plato and Confucius had different approaches to the same purpose on education, based on the same theory I put forward three ideas or hypotheses.

\subsection{Education should be leading to the human being world}

In the education world, neither is there God nor beast, whether the teachers or the students all belong to the human being. To a certain extent, the human 
being world of education is more concerned about is the natural attributes of the human being-humanity, such as human freedom, human needs, human yearning for the happiness and so on. So the understanding, attention, and respecting of the human being are important to education.

\subsection{Education should be accessible to both the knowledge and life world}

Education as maintaining human and social-cultural development, which is isolated from life can not exist. It is clear that education exists both the knowledge and life world, so it is very difficult for the teachers and the students directly into the knowledge of the world and ignoring the life world to achieve the aim of education. Therefore, the life world also comprises a significant part of education which can absorb the students into learning activity.

\subsection{Education should open into the soul and spirit world}

Living in the world of education, if the knowledge world is properly affixed into the life world we can create a harmonious atmosphere to education. The process of education between teachers and students is more than the human being world, the knowledge world, and the life world, and it is more closer to a soul and spirit world, the convection of emotion, the boosting of the will, the collision and burst of the knowledge are most important to education. The world consists of the emotion, the will and the wisdom, and the world of education is the soul and spirit world.

\section{DISCUSSION}

The whole process of education needs to accomplish three steps such as the first step of the human being world, the second step of both the knowledge world and the life world and the last step of the soul and spirit world.

\subsection{Education how leading to the human being world}

As everybody can see the world of education only owns human, not non-human. Everything in the world that can be access to education is no other than the human being. "Only the human beings in the world are the most intelligent things who need education" (Kant,1994.), "Only the human beings can educate themselves", "The humans born in the world have many undeveloped germs", Education is to make these germs grow, with a balanced development of his natural endowments (Kant,1994.)[2] and the nature of the human being is closely liked with education. There are some reasons that education exists among the humans, not animals as follows: First, humankind has his language and communicates each other easily, which depends on humankind's innate thought. In the meantime, the most important is that labor not only creates human, but also creates education. it is obvious that education without human is not exist.

Since the world of the human being is the first step of education, there are no reasons that the teachers neglect the students or don't regard them as human. On the contrary, there is a phenomenon that education deviates from the world of human. Lack of respect for the needs of the students, to suppress the personality of the students, and many other phenomena in education are commonplace. The deviation from the world of the human being in education means the access to the nonhuman or cruel beast world, which is a fatal mistake that never achieves the aim of knowledge in the process of education.

\subsection{Education how accessible to both the knowledge and life world}

The second step of education is the intersection of both the knowledge and life world, which include the knowledge world and the life world. The traditional method of education is thought that the teachers can directly impart knowledge to the students and education can directly enter into the knowledge world. In contrast, education was regarded the life world by the modernist Dewey (1956) "the nature of children to achieve their mission", which means education is life or education needs to go to the life world.[3]

It is clear that education directly into the knowledge world to achieve the aim of teacher professionalism is very difficult. The knowledge world relative to the living world, it means that uninteresting, monotonous, lack of emotion and love would make it difficult to stimulate the students to actively study with an effort. Education that was regard as "Only the world of the rational doctrine "or "the world of the dominant knowledge" highlighted the acquisition of knowledge, intelligence training goals, the dominance of articulate didactic, and intellectual training became the core one of the entire educational goals. This kind of education at best can achieve a "statement of facts the truth", and "moral legitimacy", but seriously out of the "in line with the rules of the intelligibility of language" and "inner expression of sincerity" (Habermas, 1989).[4] This will inevitably lead to cognition out of the emotion and the inclination, the teachers is isolated from education. Samely education cann't direct into the life world, where there is no knowledge. The life world is an open system that is mixed and disorderly. In such an "entropy" increasing number 
of the open system, if there is no effective supply of energy (knowledge) at any time it will lead to a decline in education quality.

Actually, the knowledge world lacks the interesting, affinity, and emotional appeal, wheres education is inseparable from the knowledge world. Samely the life world is an extremely complex world full of difficulties and challenges which needs the access of knowledge by education. "knowledge is the result of a solution to the problem situations through the operation to problematical situations." (Dewey, 1957). [5]So, how to deal with the relationship between the knowledge world and the life world is important in education.

\subsection{Education how open into the soul and spirit world}

The subject of education is the human being and the human being has the soul and spirit. Education naturally needs to enter the soul and spirit world, from a higher level, education is the open soul, the happiness of the spirit, and the awakening and consciousness of the soul.

The basic reason for that the civilization can continue is the result of education. The effectiveness of education is determined by the transmission of knowledge and innovation from generation to generation. How to transmit and innovate knowledge is the most important step for the teachers to lead the students to achieve the ultimate objectives in education. "Promoting change within the students or training the students to promote change in attitudes, knowledge, or behavior outside the classroom requires that the students have a backgrounds panning the layers of context within which the target behavior exists"( Beth S.Russell ,et al.2008) means that the teacher needs to help the students to create a harmonious, happy soul and spirit world in which they can communicate freely. [6]To foster honest and safe environments for the form of knowledge is critical, which lies in that the students can keep a good state of spirit or mind. Education activities is concerned is how best to mobilize and explore the human potential, as well as how best to promote the possibility of the human's internal soul and spirit to build.

To enter into the soul and spirit world is the most important in education, Instead of giving priority to education for knowledge. Education needs to devote itself to seeking and promoting knowledge transforming into wisdom by rational means, wisdom being the capacity to judge and realize what is the value of life for oneself and others. Wisdom includes knowledge, but knowledge includes no wisdom. Only knowledge is absorbed, can knowledge transform into wisdom. There are many differences between the absorption of knowledge and the absorption of food, the biggest difference is that the former that needs the participation of the will, emotion, interest and so on, while the latter is mechanical, and passive. A basic task ought to be to help the students know how to learn knowledge and transform knowledge into wisdom to enjoy their future happy life, which should be the ultimate goal of education.

\section{SUGGESTIONS}

The implementation of education's aim depends on that the teachers respect the students, lies in that knowledge and life in an appropriate way enter into education, more resides in the soul and spirit world. However, the teachers are always incited by the market-oriented model or bureaucratic system, which can only rely on single-objective on knowledge, the old model or system is the root of that it is too difficult for the teachers to enter the education world. Therefor, the traditional education evaluation model or system should be an academic evaluation model or academic evaluation authority, which includes the body of the assessment such as the expects, the teachers, and the students, comprises the content of the appraisal such as interest, emotion, will, knowledge, thought, wisdom, emphasizes the multiple results of the process of education. The new education evaluation system which is organized and planned in the academic power to run, changing a single mode which only to pay attention to knowledge for commercial purposes. The new evaluation system reflects the diversity of the evaluation body and the evaluation content, and attaches importance to the evaluation process. It is obvious that the new system is conducive to the attention of the teachers in the process of education, and to the hobbies, interests, emotion, knowledge, and wisdom of the students, and knowledge naturally can be linked to the students as the human being, to the life world, and to the soul and spirit world so that the teachers and the students can be leading to the education world.

\section{CONCLUSIONS AND IMPLICATIONS}

The subjectivity of education is the human being, and the education world include the complex life world, the knowledge world and the soul and spirit world. The nature of education is the soul and spirit, and the human's wisdom of education determine that the teachers should lead the students to enter the education world. The purpose of education is to link knowledge, life and wisdom together, reside education in emotion, endow education with a kind of happy psychological intention, open the door of the soul and spirit world in education and transform knowledge into wisdom naturally. Just as Lianjin 
Tian (2006) pointed out, "Philosophy of education itself should be integrated into the process of the educational activities, what education cares about is the activities where the teachers and students take part in together, and this process means that education itself.[7] And too much emphasis on the educational outcomes in educational practice must be looked at the educational tools, which means that for students to obtain the channel of knowledge is linked only by the forced indoctrination." therefor, the teachers not only make knowledge start with the life world, but also hold care, kindness, and compassion on the students as a human being. To achieve the purpose of education itself lies in the creation of a new education evaluation system so that education should be promoted not only by the teachers but also by the students themselves.

\section{REFERENCES}

[1] Manabu, Zhong Qi-quan. 2003. Curriculum and teacher: 223. BeiJin: Education Science Press.

[2] Kant(writtings), Qu Ju-Long(translqtion). 1994. Famous works of the world education (On education):498.499.

[3] John Dewey. 1956. Reconstruction in Philosophy. Boston: Beacon Press.

[4] Juergen Habermas. 1989. Communication and Socal Evolution: 2-5. Chongqing: Chongqing Press.

[5] John Dewey. 1957. Reconstruction in Philosophy. Boston: Beacon Press.

[6] Beth S.Russell, et al. 2008. Teaching Prevention on Sensitive Topics: Key Elements and Pedagogical Techniques.

[7] Lianjin Tian. 2006. On the return of the philosophy of education. Science Education, 12(3): 3-4. 